\title{
ANALISIS RASIO ALTMAN MODIFIKASI PADA PREDIKSI KEBANGKRUTAN PERUSAHAAN PROPERTY DAN REAL ESTATE YANG TERDAFTAR DI BEI
}

\author{
Anita Tri Widiyawati, Supri Wahyudi Utomo dan Nik Amah \\ Program Studi Pendidikan Akuntansi - FPIPS \\ IKIP PGRI MADIUN
}

\begin{abstract}
ABSTRAK
Penelitian ini bertujuan untuk mengetahui pengaruh rasio Altman Modifikasi terhadap prediksi kebangkrutan. Jenis penelitian ini termasuk penelitian kuantitatif. Populasi dalam penelitian ini adalah perusahaan property dan real estate yang terdaftar di BEI. Teknik pengambilan sampel menggunakan purposive sampling sehingga diperoleh sampel sejumlah 32 perusahaan property dan real estate yang menerbitkan laporan keuangannya selama tahun 2011-2013. Teknik analisis data menggunakan regresi logistik (logistic regression). Hasil penelitian menunjukkan bahwa: (1) working capital/total asset tidak berpengaruh terhadap prediksi kebangkrutan; (2) retained earning/total asset tidak berpengaruh terhadap prediksi kebangkrutan; (3) earning before interest and tax/total asset berpengaruh terhadap prediksi kebangkrutan; (4) market value of equity/book value of equity tidak berpengaruh terhadap prediksi kebangkrutan; (5) rasio Altman Modifikasi secara simultan berpengaruh terhadap prediksi kebangkrutan. Rasio Altman Modifikasi terbukti secara bersama-sama dapat digunakan untuk memprediksi kebangkrutan.
\end{abstract}

Kata Kunci : Prediksi Kebangkrutan, Rasio Altman Modifikasi

\section{PENDAHULUAN}

Setiap perusahaan tidak akan pernah lepas dari suatu permasalahan. Salah satu permasalahan yang paling sering dialami oleh perusahaan adalah masalah keuangan. Permasalahan keuangan dapat menyebabkan perusahaan mengalami kesulitan untuk menjalankan aktivitasnya. Kegiatan perusahaan akan tersendat sehingga tidak menutup kemungkinan perusahaan akan bangkrut. Berawal dari masalah keuangan yang dialami perusahaan, apabila dibiarkan berlarut-larut dan tidak cepat diatasi dapat mengakibatkan kebangkrutan. Situasi dimana suatu perusahaan menghadapi masalah kesulitan keuangan sering disebut dengan financial distress dan jika kondisi kesulitan tersebut tidak cepat diatasi maka bisa berakibat kebangkrutan usaha (bankruptcy).

Upaya untuk menghindari kebangkrutan perlu dilakukan oleh suatu perusahaan agar tetap bertahan di dunia usaha maupun bisnis baik untuk perusahaan yang sudah go public ataupun belum go public. Hal ini dikarenakan kebangkrutan perusahaan akan menimbulkan berbagai permasalahan seperti meningkatnya angka pengangguran, meningkatnya angka kriminalitas, berkurangnya pendapatan Negara, serta dampak lain pada perusahaan yang selama ini menjadi mitra kerja perusahaan yang mengalami kebangkrutan. Dampak negatif dari kebangkrutan suatu perusahaan dapat diminimalisir apabila hal tersebut dapat diprediksi sebelumnya.

Saat ini ada banyak formula yang telah dikembangkan untuk menjawab berbagai permasalahan tentang kebangkrutan ini, salah satu yang dianggap populer serta analisis secara umum adalah model kebangkrutan Altman atau lebih dikenal dengan model Altman Z-score yang menggunakan beberapa rasio untuk menciptakan alat prediksi kesulitan. Altman Z-score menggunakan teknik statistik (analisis diskriminan berganda - multiple discriminant analysis) untuk menghasilkan alat prediksi yang merupakan fungsi linier dari beberapa variabel penjelas (Subramanyam dan Wild, 2010: 288). 
Penelitian tentang Altman Z-score telah banyak dilakukan. Nugroho dan Mawardi (2012) juga melakukan penelitian terkait dengan analisis prediksi financial distress dengan menggunakan model Altman Z-Score Modifikasi 1995 pada perusahaan manufaktur yang go public di Indonesia periode 2008-2010. Hasil penelitian menunjukkan bahwa rasio Altman Modifikasi yaitu Net working capital to Total assets (X1), Retained Earning to Total Assets (X2), Earning before interest and tax to Total Assets (X3), dan Book value of equity to Total liability (X4) mempunyai pengaruh positif terhadap prediksi financial distress.

Martha (2012) juga melakukan penelitian terkait dengan prediksi financial distress pada perusahaan ritel dan wholesale yang terdaftar di BEI periode 2008-2011 dengan menggunakan rasio model Altman. Hasil penelitian menunjukkan bahwa pada model terjadi multikolinieritas sehingga variabel Retained Earnings to Total Assets dihapus agar model bebas dari multikolinieritas. Secara simultan variabel Net working capital to Total assets, Earning before interest and tax to Total Assets, dan Book value of equity to Total liability berpengaruh signifikan terhadap prediksi financial distress. Secara parsial, rasio net working capital to total assets dan earning before interest and tax to total assets tidak berpengaruh terhadap prediksi financial distress. Sedangkan rasio book value of equity to total debt berpengaruh signifikan terhadap prediksi financial distress.

Dari dua penelitian terdahulu tersebut terdapat perbedaan objek dan hasil penelitian dengan menggunakan analisis model Altman yang sama yaitu Altman Modifikasi. Berdasarkan latar belakang permasalahan yang telah dipaparkan di atas, maka peneliti tertarik dan terdorong untuk melakukan penelitian dengan judul "Pengaruh Rasio Altman Modifikasi terhadap Prediksi Kebangkrutan pada Perusahaan Property dan Real Estate yang Terdaftar di Bursa Efek Indonesia Periode 2011-2013".

\section{TELAAH LITERATUR}

\section{Kebangkrutan}

Kesulitan keuangan (financial distress) yang dialami suatu perusahaan, jika tidak cepat diatasi maka ini bisa berakibat kebangkrutan usaha (bankruptcy). Kesulitan keuangan merupakan tanda-tanda awal sebuah perusahaan akan mengalami kebangkrutan. Darsono dan Ashari (2005: 101) menjelaskan bahwa kesulitan keuangan dapat diartikan sebagai ketidakmampuan perusahaan untuk membayar kewajiban keuangannya pada saat jatuh tempo yang menyebabkan kebangkrutan perusahaan. Financial distress dimulai dari ketidakmampuan dalam memenuhi kewajiban-kewajibannya, terutama kewajiban yang bersifat jangka pendek termasuk kewajiban likuiditas, dan juga termasuk kewajiban dalam kategori solvabilitas. Selain itu dalam penelitiannya, Endri (2009: 38) menyimpulkan bahwa kebangkrutan adalah suatu keadaan atau situasi dimana perusahaan gagal atau tidak mampu lagi memenuhi kewajiban-kewajiban kepada debitur karena perusahaan mengalami kekurangan dan ketidakcukupan dana untuk menjalankan atau melanjutkan usahanya sehingga tujuan ekonomi yang ingin dicapai oleh perusahaan tidak dapat dicapai yaitu profit.

Berdasarkan pendapat di atas, maka dapat disimpulkan bahwa kebangkrutan merupakan kegagalan perusahaan untuk melunasi kewajiban jangka pendek maupun jangka panjang yang dikarenakan tidak mampu menghasilkan laba. Perusahaan yang tidak mampu menghasilkan laba (defisit) akan terancam mengalami kebangkrutan sebab dengan laba yang diperoleh perusahaan bisa digunakan untuk mengembalikan pinjaman, membiayai operasi perusahaan dan kewajiban-kewajiban yang harus dipenuhi bisa ditutup dengan laba atau aktiva yang dimiliki.

\section{Rasio Altman Modifikasi}

Pada tahun 1968, Edward I. Altman (Assistant Proffesor of Finance di Universitas New York) memberikan formula yang berfungsi untuk memprediksi potensi kebangkrutan suatu 
perusahaan. Altman mempergunakan angka-angka di dalam laporan keuangan dan merepresentasikannya dalam suatu angka, yaitu Z-Score yang dapat menjadi acuan untuk menentukan apakah suatu perusahaan berpotensi untuk bangkrut atau tidak (Parahita, 2012).

Z-Score merupakan suatu persamaan multi variabel yang digunakan oleh Altman dalam rangka memprediksi tingkat kebangkrutan (Prihadi, 2009: 81). Altman (1968) memprediksi kebangkrutan dengan menggunakan 66 sampel perusahaan yang kemudian sampel tersebut dibagi lagi menjadi dua bagian yaitu 33 bangkrut dan 33 tidak bangkrut. Altman Z-Score menggunakan beberapa rasio untuk menciptakan alat prediksi kesulitan. Altman Z-Score menggunakan teknik statistik (analisis diskriminan berganda - Multiple Discriminant Analysis) untuk menghasilkan alat prediksi yang merupakan fungsi linier dari beberapa variabel penjelas (Subramanyam dan Wild, 2010: 288). Secara matematis persamaan Z-Score Altman dapat dirumuskan sebagai berikut (Prihadi, 2009: 82):

$$
\text { Z-Score }=1.2 \mathrm{X}_{1}+1.4 \mathrm{X}_{2}+3.3 \mathrm{X}_{3}+0.6 \mathrm{X}_{4}+1.0 \mathrm{X}_{5}
$$

Namun persamaan Z-Score di atas hanya digunakan pada perusahaan yang go public atau memiliki nilai pasar dan perusahaan nonmanufaktur tidak dapat diprediksi dengan rumus ini. Maka, model yang telah dikembangkan oleh Altman ini mengalami suatu revisi. Menurut Subramanyam dan Wild (2010: 288), model ini (Altman Revised) lebih umum dibandingkan dengan model awal tahun 1968 yang hanya dapat diterapkan pada perusahaan yang sahamnya diperdagangkan di bursa efek. Penggunaan model awal bisa dilakukan jika hanya diterapkan pada emiten. Model baru ini dapat diterapkan pada perusahaan emiten maupun non-emiten. Terdapat sedikit perubahan pada nilai $\mathrm{X}_{4}$ dalam model Altman Revised dimana $\mathrm{X}_{4}=$ book value of equity/book value of debt.

Adapun model Altman Revisi adalah sebagai berikut:

$$
Z^{\prime} \text {-Score }=0.717 \mathrm{X}_{1}+0.847 \mathrm{X}_{2}+3.107 \mathrm{X}_{3}+0.42 \mathrm{X}_{4}+0.998 \mathrm{X}_{5}
$$

Setelah itu, Altman mengembangkan model formulanya agar lebih fleksibel yang dapat digunakan untuk perusahaan nonmanufaktur dengan menghilangkan ratio kelima $\left(\mathrm{X}_{5}\right)$ yang merupakan ratio penjualan/total asset. Z"-Score merupakan rumus paling fleksibel karena bisa digunakan untuk perusahaan publik maupun private (Prihadi, 2009: 84). Sehingga dalam perkembangannya model Altman terbagi menjadi 3 sesuai kategori jenis perusahaan (Gamayuni, 2011), yakni: (1) Original Z-score, suatu analisis z-score untuk perusahaan public manufacturer (Altman 1968), (2) Model A Z-score, suatu analisis z-score untuk private manufacturer (Altman Revisi), dan Model B Z-score, suatu analisis z-score untuk private general firm (Altman Modifikasi).

Adapun formula untuk model Altman Modifikasi adalah sebagai berikut:

$$
\begin{aligned}
& Z "-S c o r e=6.56 \mathrm{X}_{1}+3.26 \mathrm{X}_{2}+6.72 \mathrm{X}_{3}+1.05 \mathrm{X}_{4} \\
& \text { Keterangan: } \\
& \mathrm{X}_{1} \quad=\text { working capital/total asset } \\
& \mathrm{X}_{2} \quad=\text { retained earning/total asset } \\
& \mathrm{X}_{3}=\text { earning before interest and taxes/total asset } \\
& \mathrm{X}_{4}=\text { market value of equity/book value of debt }
\end{aligned}
$$


Kriteria yang digunakan untuk memprediksi kebangkrutan perusahaan dengan model ini adalah:

$\begin{array}{ll}Z>2.60 & : \text { perusahaan sehat } \\ 2.60<Z<1.10 & \text { : perusahaan pada grey area atau daerah kelabu } \\ Z<1.10 & \text { : perusahaan potensial bangkrut }\end{array}$

Rasio Altman Modifikasi inilah yang nantinya akan digunakan dalam penelitian yang akan dilakukan peneliti untuk memprediksi kebangkrutan perusahaan. Adapun uraian dari masing-masing rasio yang digunakan adalah:

a) Working Capital/Total Asset

Menurut Subramanyam dan Wild (2010: 241), modal kerja (working capital) adalah selisih aset lancar setelah dikurangi kewajiban lancar. Modal kerja penting untuk mengukur cadangan likuiditas. Maka, rasio ini merupakan salah satu rasio likuiditas. Fahmi (2013: 116) menjelaskan bahwa rasio likuiditas ini penting karena kegagalan dalam membayar kewajiban dapat menyebabkan kebangkrutan perusahaan.

Bila perusahaan mengalami kesulitan keuangan, modal kerja akan turun lebih cepat daripada total aktiva yang menyebabkan ratio ini turun. Modal kerja bersih yang negatif yaitu apabila nilai hutang lancar yang lebih besar dibandingkan dengan nilai aktiva lancar, kemungkinan besar perusahaan akan menghadapi masalah dalam menutupi kewajiban jangka pendeknya karena tidak tersedianya aktiva lancar yang cukup untuk menutupi kewajiban tersebut. Sebaliknya, perusahaan dengan modal kerja bersih yang bernilai positif yaitu apabila nilai aktiva lancar lebih besar dibandingakn dengan nilai hutang lancar, jarang sekali menghadapi kesulitan dalam melunasi kewajibannya (Endri, 2009).

Berdasarkan penjelasan di atas, rasio working capital/total asset merupakan rasio yang dapat menggambarkan likuiditas perusahaan. Nilai modal kerja yang semakin menurun dibanding total aktiva menyebabkan perusahaan kesulitan untuk melunasi kewajiban jangka pendeknya. Maka, semakin kecil nilai rasio ini dapat memberikan indikasi bahwa perusahaan mengalami kesulitan keuangan yang menyebabkan kebangkrutan perusahaan.

b) Retained Earning/ Total Asset

Rasio ini menunjukkan kemampuan perusahaan untuk menghasilkan laba ditahan dari total aktiva perusahaan. Laba ditahan adalah modal yang berasal dari hasil operasi perusahaan yang ditahan sebelum dibagikan dalam bentuk dividen (Sunyoto, 2013: 33). Maka, laba ditahan menunjukkan berapa banyak pendapatan perusahaan yang tidak dibayarkan dalam bentuk deviden kepada para pemegang saham. Ratio ini juga mencerminkan umur perusahaan, karena semakin muda perusahaan, semakin sedikit waktu yang dimilikinya untuk membangun laba kumulatifnya. Bila perusahaan mulai merugi, maka nilai dari total laba ditahan juga akan mulai menurun (Sinarwati, 2012).

Berdasarkan penjelasan di atas, retained earning/total asset merupakan perbandingan antara laba ditahan dengan total aktiva. Nilai laba ditahan akan menurun jika perusahaan mengalami kerugian. Maka, semakin kecil peranan laba ditahan terhadap total aktiva menunjukkan kemungkinan financial distress perusahaan akan semakin tinggi.

\section{c) Earning Before Interest And Taxes/ Total Asset}

EBIT merupakan laba yang diperoleh perusahaan sebelum dikurangi pajak dan bunga. Rasio ini merupakan ukuran produktivitas dari aktiva perusahan yang sesungguhnya terlepas dari pajak. Keadaan bangkrut terjadi saat total kewajiban melebihi penilaian wajar perusahaan terhadap aset perusahaan dengan nilai ditentukan 
oleh kemampuan aset menghasilkan laba (Gamayuni, 2011). Semakin rendah rasio EBIT terhadap total aktiva menunjukkan semakin kecilnya kemampuan perusahaan dalam menghasilkan laba sebelum bunga dan pajak dari aktiva yang digunakan sehingga probabilitas perusahaan terhadap kondisi financial distress adalah semakin tinggi (Maulana, 2010).

Rasio earning before interest and tax/total asset merupakan rasio profitabilitas perusahaan yaitu kemampuan perusahaan dalam memperoleh laba/keuntungan. Semakin kecil nilai rasio ini, maka kemungkinan kebangkrutan adalah semakin tinggi.

\section{d) Market Value Of Equity/ Book Value of Debt}

Rasio ini menunjukkan kemampuan perusahaan untuk memenuhi kewajibankewajiban dari nilai pasar modal sendiri (saham biasa). Nilai pasar ekuitas (market value of equity) diperoleh dari jumlah lembar saham beredar dikalikan harga saham (Sartono, 2010: 103). Sementara nilai buku hutang diperoleh dengan menjumlahkan hutang jangka panjang dengan hutang jangka pendek.

Maulana (2010) menjelaskan hubungan rasio nilai buku modal terhadap nilai buku hutang dengan kondisi financial distress adalah negatif. Semakin rendah rasio nilai buku modal terhadap nilai buku hutang menunjukkan semakin kecilnya kemampuan perusahaan dalam memenuhi kewajiban jangka panjangnya dari modal sendiri, sehingga probablitas perusahaan terhadap financial distress adalah semakin tinggi.

Berdasarkan penjelasan di atas, maka rasio market value of equity/book value of debt merupakan rasio yang mencerminkan kemampuan perusahaan untuk memenuhi kewajibannya dengan modal sendiri. Semakin kecil nilai rasio ini, maka semakin tinggi resiko kebangkrutan yang akan dialami perusahaan.

\section{HIPOTESIS PENELITIAN}

$\mathrm{H}_{1}$ : Working capital/total asset berpengaruh terhadap prediksi kebangkrutan

$\mathrm{H}_{2}$ : Retained earning/total asset berpengaruh terhadap prediksi kebangkrutan

$\mathrm{H}_{3}$ : Earning before interest and tax/total asset berpengaruh terhadap prediksi kebangkrutan

$\mathrm{H}_{4}$ : Market value of equity/book value of debt berpengaruh terhadap prediksi kebangkrutan

$\mathrm{H}_{5}$ : Rasio Altman Modifikasi berpengaruh secara simultan terhadap prediksi kebangkrutan

\section{METODE PENELITIAN}

Populasi dalam penelitian ini adalah perusahaan property dan real estate yang terdaftar di Bursa Efek Indonesia. Berdasarkan data yang diperoleh peneliti, jumlah perusahaan property dan real estate yang terdaftar di Bursa Efek Indonesia adalah 46 perusahaan. Sampel penelitian diambil dari populasi yang ada dengan menggunakan teknik purposive sampling yaitu teknik penentuan sampel dengan pertimbangan tertentu (Sugiyono, 2014: 126). Berdasarkan kriteria tersebut dapat diperoleh sampel penelitian sebanyak 32 perusahaan. Jenis data yang digunakan yaitu data deret berkala (time series). Dalam penelitian ini kurun waktu yang diteliti mulai tahun 2011 sampai dengan 2013. Data yang dikumpulkan bersumber dari data sekunder yaitu data yang sudah diproses oleh pihak tertentu. Keseluruhan data dari perusahaan property dan real estate yang go public yang diperlukan dalam penelitian diperoleh dari website resmi BEI yaitu www.idx.co.id.

Untuk menghindari penafsiran ganda dan memudahkan dalam melakukan penelitian terhadap variabel yang diteliti, maka dalam penelitian ini memberikan definisi operasional dan cara pengukuran variabel yang dipergunakan dalam penelitian, yaitu sebagai berikut:

a) Working Capital To Total Asset $\left(\mathrm{X}_{1}\right)$

Rasio ini mengukur kemampuan perusahaan dalam memenuhi kewajiban jangka pendek, semakin kecil rasio menunjukkan kondisi likuid perusahaan yang semakin 
memburuk (Maulana, 2010). Berikut disajikan rumus untuk mencari nilai variabel $\mathrm{X}_{1}$ (Hanafi dan Halim, 2012: 272):

Rumus $\mathrm{X}_{1}$ :

$\begin{aligned} & \text { Working capital } \\ & \text { to total asset }\end{aligned}=\frac{\text { Modal Kerja }}{\text { Total aktiva }}=\frac{\text { Aktiva lancar }- \text { Hutang lancar }}{\text { Total aktiva }}$

b) Retained Earning To Total Asset $\left(\mathrm{X}_{2}\right)$

Rasio ini menunjukkan kemampuan perusahaan untuk menghasilkan laba ditahan dari total aktiva perusahaan (Endri, 2009). Adapun rumus untuk mencari nilai variabel $\mathrm{X}_{2}$ adalah sebagai berikut (Darsono dan Ashari, 2005: 106):

Rumus $\mathrm{X}_{2}$ :

Retained earning to total
asset

c) Earning Before Interest and Tax To Total Asset ( $\left.\mathrm{X}_{3}\right)$

Rasio ini menunjukkan kemampuan perusahaan untuk menghasilkan laba dari aktiva yang digunakan sebelum pembayaran bunga dan pajak (Nugroho dan Mawardi, 2012). Berikut disajikan rumus untuk mencari nilai variabel $X_{3}$ (Darsono dan Ashari, 2005: 106):

Rumus $\mathrm{X}_{3}$ :

$\begin{aligned} & \text { Earning before interest } \\ & \text { and tax to total asset }\end{aligned} \quad=\frac{\text { Laba sebelum bunga dan pajak }}{\text { Total aktiva }}$

d) Market Value of Equity To Book Value of Debt $\left(\mathrm{X}_{4}\right)$

Rasio ini menunjukkan kemampuan perusahaan untuk memenuhi kewajibankewajiban dari nilai pasar modal sendiri (Endri, 2009). Nilai pasar modal adalah jumlah saham yang beredar kali harga saham (Sartono, 2010: 103), sedangkan hutang mencakup hutang jangka panjang dan hutang lancar.

Rumus $\mathrm{X}_{4}$ :

$\begin{aligned} & \text { Market value of equity to } \\ & \text { book value of debt }\end{aligned}=\begin{aligned} & \text { Nilai pasar modal } \\ & \text { Nilai buku hutang }\end{aligned}$

$=\frac{\text { Jumlah saham beredar } \mathrm{x} \text { harga saham }}{\text { Hutang jangka panjang }+ \text { Hutang lancar }}$

e) Prediksi Kebangkrutan (Y)

Dalam penelitian ini, perusahaan dikelompokkan menjadi dua kelompok berdasarkan keadaannya, yaitu:

1. Perusahaan yang mengalami rugi selama dua tahun berturut-turut pada tahun 2011-2013 diprediksikan mengalami kebangkrutan ( $Y=1)$

2. Perusahaan yang mengalami laba selama dua tahun berturut-turut pada tahun 2011-2013 diprediksikan tidak mengalami kebangkrutan $(\mathrm{Y}=0)$ 
ANALISIS DATA

Teknik analisis data yang digunakan dalam penelitian ini adalah regresi logistik. Regresi logistik sama seperti regresi berganda, bedanya variabel dependen pada regresi logistik berbentuk kategorial (Latan dan Temalagi, 2013: 92). Adapun langkah-langkah teknik analisis data dalam penelitian ini adalah sebagai berikut:

Pengolahan data menggunakan software IBM SPSS versi 22 dengan menggunakan regresi logistik. Variabel terikatnya berupa data kategorikal yaitu kode 0 untuk prediksi tidak bangkrut dan kode 1 untuk prediksi bangkrut. Langkah-langkah dalam pengolahan data adalah sebagai berikut:

a. Statistik Deskriptif

b. Uji kelayakan dari model regresi logistik yang didasarkan pada:

1) Uji Keseluruhan Model (Overall model fit)

2) Uji Hosmer and Lemeshow

3) Uji Nagelkerke R Square

4) Uji Matrik Klasifikasi

c. Pengujian Hipotesis

1) Pengujian secara Parsial

Pengujian hipotesis secara parsial yaitu pengaruh masing-masing variabel independen terhadap variabel dependen, dapat dilihat dari nilai signifikan yang didapat dari hasil olah data. Hasil pengujian ini dapat dilihat dalam output regression logistic pada Variables in the Equation. Kriteria pengujian hipotesis adalah sebagai berikut:

a) Tingkat kepercayaan yang digunakan adalah $95 \%$ atau taraf signifikansi $5 \%$ $(\alpha=0,05)$.

b) Kriteria penerimaan atau penolakan hipotesis didasarkan pada signifikansi $p$ value, yaitu:

Jika taraf signifikansi > 0,05 maka Ha ditolak atau hipotesis yang menyatakan variabel bebas berpengaruh terhadap variabel terikat yang ditolak.

Jika taraf signifikansi $<0,05$ maka Ha diterima atau hipotesis yang menyatakan variabel bebas berpengaruh terhadap variabel terikat yang diterima.

2) Pengujian secara Simultan

Pengujian hipotesis secara simultan yaitu menguji pengaruh variabel independen secara bersama-sama terhadap variabel dependen. Hasil pengujian ini dapat dilihat dalam output output regression logistic pada tabel Omnibus Test of Model Coefficients. Dimana jika nilai signifikansi lebih kecil dari 0,05 $(<0,05)$, maka Ha diterima sehingga dapat disimpulkan bahwa variabel independen secara bersamasama berpengaruh signifikan terhadap variabel dependen.

\section{HASIL PENELITIAN}

1. Uji Kelayakan Model Regresi Logistik

a) Uji Keseluruhan Model (Overall model fit)

\section{Tabel 1}

Analisis Keseluruhan Model (Overall Model Fit)

\begin{tabular}{lll}
\hline \multirow{2}{*}{ Iteration } & $\begin{array}{l}-2 \text { Log } \\
\text { Likelihood }\end{array}$ & $\begin{array}{l}\text { Coefficients } \\
\text { Constant }\end{array}$ \\
\hline Step 0 & 64,155 & $-2,152$ \\
Step 1 & 15,175 & $-2,483$ \\
\hline
\end{tabular}

Dari hasil analisis Overall Model Fit pada tabel 4.3 menunjukkan bahwa model analisis yang lebih baik. Hal ini diketahui adanya penurunan nilai -2Log Likelihood 
yaitu 64,155 pada block 0 menjadi 15,175 pada block 1 atau terjadi penurunan Chi Square sebesar 48,981. Maka, dapat disimpulkan bahwa model regresi logistik secara keseluruhan layak digunakan.

b) Uji Hosmer and Lemeshow

Tabel 2

Kesamaan Prediksi Model Regresi Logistik Hosmer and Lemeshow Test

\begin{tabular}{llll}
\hline Step & Chi-square & df & Sig. \\
\hline 1 & 0,486 & 8 & 1,000 \\
\hline
\end{tabular}

Berdasarkan tabel 4.3 hasil pengujian kesamaan prediksi model regresi logistik dengan data observasi menunjukkan bahwa nilai chi-square sebesar 0,486 dengan nilai signifikan sebesar 1,000. Nilai signifikan tersebut lebih besar dari 0,05 $(>0,05)$, maka tidak diperoleh adanya perbedaan antara prediksi model regresi logistik dengan data hasil observasi. Hal ini berarti bahwa model mampu diterima karena model sesuai dengan hasil observasinya.

c) Uji Nagelkerke R Square

Tabel 3

Nilai Nagelkerke $R$ Square

\begin{tabular}{llll}
\hline \multicolumn{5}{c}{ Nilai Nagelkerke R Square } \\
Step & -2 Log & Cox \& Snell R & Nagelkerke \\
& likelihood & Square & R Square \\
\hline 1 & 15,175 & 0,400 & 0,820 \\
\hline
\end{tabular}

Berdasarkan hasil nilai Nagelkerke $R$ Square pada tabel 4.4 menunjukkan bahwa nilai Nagelkerke $R$ Square adalah 0,820 yang variabilitas variabel dependen yang dapat dijelaskan oleh variabel independen adalah $82 \%$ sisanya sebesar $18 \%$ dijelaskan oleh variabel-variabel lain di luar model penelitian. Atau dengan kata lain rasio X1 (Working Capital/Total Asset), X2 (Retained Earning/Total Asset), X3 (Earning Before Interest and Tax/Total Asset), dan X4 (Market Value of Equity/Book Value of Debt) dapat menjelaskan variabel prediksi kebangkrutan sebesar $82 \%$.

d) Uji Matrik Klasifikasi

\section{Tabel 4}

Uji Matrik Klasifikasi

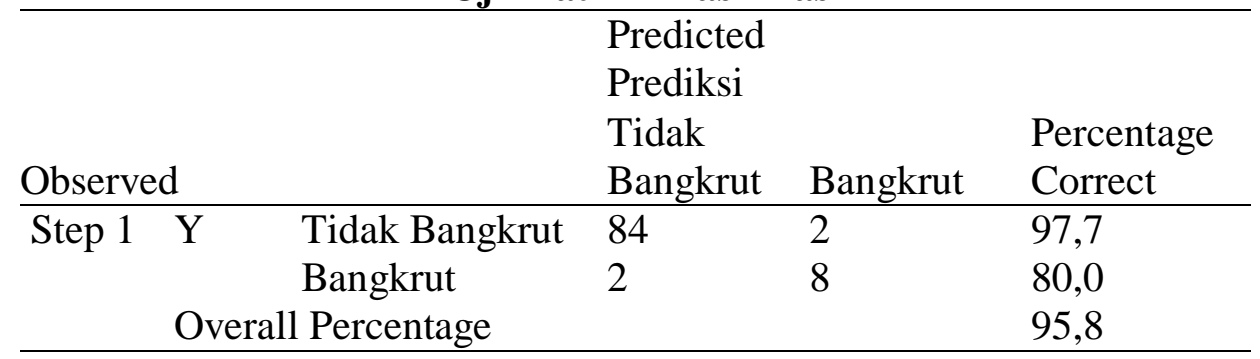

Berdasarkan hasil uji matrik klasifikasi pada tabel 4.5 menunjukkan bahwa dari 86 perusahaan kategori tidak bangkrut yang benar tidak mengalami kebangkrutan ada 84 perusahaan sedang 2 perusahaan masuk kategori bangkrut dengan nilai untuk tingkat kebenaran perusahaan yang tidak mengalami kebangkrutan adalah 97,7\%. Sementara dari 10 perusahaan kategori bangkrut yang benar masuk kategori bangkrut ada 8, sedangkan 2 perusahaan yang lain masuk kategori tidak bangkrut dengan nilai tingkat 
kebenaran klasifikasi untuk perusahaan yang mengalami kebangkrutan adalah $80 \%$. Ketepatan prediksi keseluruhan model ini adalah 95,8\%.

\section{Uji Hipotesis}

1) Pengujian secara Parsial

\section{Tabel 5}

Variables in the Equation

\begin{tabular}{lllllllll}
\hline & & \multicolumn{1}{c}{ B } & \multicolumn{1}{c}{ S.E. } & \multicolumn{1}{c}{ Wald } & df & Sig. & Exp(B) \\
\hline Step 1 & a & X1 & 2,739 & 2,947 &, 864 & 1 & 0,353 & 15,478 \\
& X2 & $-6,724$ & 4,855 & 1,918 & 1 & 0,166 & 0,001 \\
& X3 & $-58,267$ & 22,382 & 6,777 & 1 & 0,009 & 0,000 \\
& X4 & 0,246 & 0,230 & 1,152 & 1 & 0,283 & 1,279 \\
& Constant & $-2,483$ & 1,107 & 5,032 & 1 & 0,025 & 0,083 \\
\hline
\end{tabular}

Pada tabel 5 menunjukkan nilai signifikan yang dijadikan acuan dalam diterima atau ditolaknya hipotesis. Berikut penjelasan mengenai hipotesis dalam penelitian ini.

a. Working Capital/Total Asset berpengaruh terhadap prediksi kebangkrutan

Variabel $\mathrm{X}_{1}$ (Working Capital/Total Asset) pada tabel 4.6 menunjukkan nilai signifikan 0,353 . Tingkat signifikan yang digunakan sebesar 0,05 berarti nilai 0,353 > 0,05 ini mengidentifikasi bahwa Ha ditolak, sehingga dari hasil penelitian terbukti bahwa rasio working capital/total asset tidak berpengaruh terhadap prediksi kebangkrutan.

Tidak adanya pengaruh rasio working capital to total asset terhadap prediksi kebangkrutan disebabkan oleh besarnya rasio working capital/total asset perusahaan property dan real estate yang berfluktuasi setiap tahunnya selama periode pengamatan. Sehingga perusahaan tidak memperhatikan rasio working capital/total asset untuk memprediksi kebangkrutan.

Modal kerja merupakan keseluruhan aktiva lancar yang tersedia untuk membiayai kegiatan operasional perusahaan sehari-hari, dimana besarnya modal kerja tersebut dapat ditentukan oleh jenis dan aktivitas perusahaan. Perusahaan sampel merupakan perusahaan yang bergerak dalam bidang property dan real estate yang mempunyai persediaan berupa tanah, bangunan, gedung, apartemen, dan sebagainya. Maka, nilai persediaan perusahaan property dan real estate tergolong besar. Penjualan persediaan yang tidak menentu setiap tahunnya menyebabkan modal kerja perusahaan juga tidak dapat diprediksikan oleh perusahaan. Hal inilah yang menyebabkan besarnya working capital to total asset berfluktuasi setiap tahunnya sehingga tidak berpengaruh terhadap prediksi kebangkrutan.

b. Retained Earning/Total Asset berpengaruh terhadap prediksi kebangkrutan

Variabel $\mathrm{X}_{2}$ (Retained Earning/Total Asset) pada tabel 4.6 menunjukkan nilai signifikan 0,166. Tingkat signifikan yang digunakan sebesar 0,05 berarti nilai 0,166 > 0,05 ini mengidentifikasi bahwa Ha ditolak, sehingga dari hasil penelitian terbukti bahwa rasio retained earning/total asset tidak berpengaruh terhadap prediksi kebangkrutan.

Tidak berpengaruhnya rasio retained earning/total asset dalam penelitian ini dikarenakan besarnya laba ditahan yang cenderung meningkat selama periode pengamatan. Laba ditahan akan menunjukkan berapa banyaknya pendapatan perusahaan yang tidak dibayarkan dalam bentuk deviden kepada para pemegang saham. Perusahaan kurang memperhatikan besarnya rasio ini untuk memprediksi kebangkrutan perusahaan dikarenakan rasio ini kurang dapat menunjukkan adanya 
prediksi kebangkrutan jika dilihat dari peningkatan dan penurunan laba operasi perusahaan. Sehingga tinggi rendahnya laba ditahan tidak mempengaruhi besarnya laba operasi yang diterima oleh perusahaan.

c. Earning Before Interest and Tax/Total Asset berpengaruh terhadap prediksi kebangkrutan

Variabel $\mathrm{X}_{3}$ (Earning Before Interest and Tax /Total Asset) pada tabel 4.6 menunjukkan nilai signifikan 0,009. Tingkat signifikan yang digunakan sebesar 0,05 berarti nilai $0,009>0,05$ ini mengidentifikasi bahwa Ha diterima, sehingga dari hasil penelitian terbukti bahwa rasio earning before interest and tax/total asset berpengaruh terhadap prediksi kebangkrutan.

Adanya pengaruh earning before interest and tax/total asset terhadap prediksi kebangkrutan dikarenakan kemampuan menghasilkan laba (profitabilitas) perusahaan property dan real estate tergolong rendah. Hal ini ditunjukkan pula dengan nilai maksimum variabel yang diperoleh adalah sebesar $34 \%$ dari sampel yang digunakan.

Menurut teori, rasio earning before interest and tax/total asset yang tinggi menunjukkan bahwa manajemen mampu mengelola aktiva perusahaan dengan baik sehingga perusahaan memperoleh laba yang tinggi. Namun berdasarkan analisis data menunjukkan nilai rasio earning before interest and tax/total asset perusahaan property dan real estate yang rendah sehingga perusahaan memperoleh laba yang rendah pula. Rendahnya laba perusahaan property dan real estate dapat dikarenakan rendahnya penjualan dan tingginya biaya yang dikeluarkan perusahaan mengingat produk yang dijual oleh perusahaan bukan produk yang dikonsumsi untuk kebutuhan sehari-hari sehingga dibutuhkan biaya yang besar pula untuk merawat persediaan perusahaan. Maka indikator yang dapat digunakan untuk mendeteksi kebangkrutan berdasarkan rasio ini adalah rugi terus menerus, penjualan yang menurun, piutang dagang menimgkat, persediaan meningkat, dan sebagainya. Sehingga, perusahaan dapat menggunakan rasio earning before interest and tax/total asset untuk memprediksi kebangkrutan. Tinggi rendahnya laba dapat digunakan perusahaan untuk mengukur kinerja perusahaan.

d. Market Value of Equity/Book Value of Debt berpengaruh terhadap prediksi kebangkrutan

Variabel $\mathrm{X}_{4}$ (Market Value of Equity/Book Value of Debt) pada tabel 4.6 menunjukkan nilai signifikan 0,283. Tingkat signifikan yang digunakan sebesar 0,05 berarti nilai $0,283>0,05$ ini mengidentifikasi bahwa Ha ditolak, sehingga dari hasil penelitian terbukti bahwa rasio market value of equity/book value of debt tidak berpengaruh terhadap prediksi kebangkrutan.

Tidak adanya pengaruh rasio market value of equity/book value of debt terhadap prediksi kebangkrutan dalam penelitian ini dikarenakan nilai pasar modal (market value of equity) yang cenderung konstan/tetap setiap tahunnya sementara total utang perusahaan yang berubah-ubah bahkan cenderung meningkat. Maka perusahaan kurang begitu memperhatikan nilai rasio market value of equity/book value of debt untuk memprediksi kebangkrutan.

Market value of equity nilainya tetap disebabkan karena perusahaan lebih memilih utang untuk dijadikan sebagai sumber pendanaan perusahaan karena biaya transaksi penerbitan utang daripada transaksi penerbitan saham. Sehingga jika perusahaan mempunyai nilai pasar saham yang besar belum tentu perusahaan tidak mengalami kesulitan keuangan yang dapat menyebabkan kebangkrutan. 
2) Pengujian secara Simultan

\section{Tabel 6}

Omnibus Tests of Model Coefficients

\begin{tabular}{lllll}
\hline & & Chi-square & df & Sig. \\
\hline Step 1 & Step & 48,981 & 4 & 0,000 \\
& Block & 48,981 & 4 & 0,000 \\
& Model & 48,981 & 4 & 0,000 \\
\hline
\end{tabular}

Hasil Omnibus Test of Model Coefficients pada tabel 4.7 di atas menunjukkan bahwa nilai Chi-square sebesar 48,981 dengan degree of freedom $=4$ dan tingkat signifikansi sebesar 0,000. Nilai signifikansi tersebut jauh lebih kecil dari 0,05, maka Ha diterima yang artinya bahwa variabel rasio Altman Modifikasi secara bersama-sama berpengaruh signifikan terhadap prediksi kebangkrutan.

Secara keseluruhan rasio Altman Modifikasi dapat memprediksi permasalahan keuangan yang dialami perusahaan hingga mengalami kebangkrutan. Rasio yang pertama yaitu rasio working capital/total asset yang menunjukkan tingkat likuiditas perusahaan. Semakin kecil nilai rasio tersebut, tingkat prediksi kebangkrutan akan semakin meningkat. Rasio kedua yaitu retained earning/total asset yang menunjukkan kemampuan perusahaan untuk menghasilkan laba ditahan yang berkaitan dengan pemberian deviden kepada investor. Rasio ketiga yaitu EBIT/total asset yang mencerminkan kemampuan perusahaan dalam memperoleh laba (profitabilitas). Rasio keempat yaitu market value of equity/book value of debt yang menunjukkan kemampuan perusahaan untuk menjamin hutang-hutangnya dengan modal sendiri.

Antara variabel yang satu dengan yang lainnya dalam rasio Altman Modifikasi memiliki hubungan yang saling mempengaruhi. Nilai modal kerja yang besar menunjukkan produktivitas aktiva perusahaan yang mampu menghasilkan laba usaha yang besar seperti yang diharapkan perusahaan. Meningkatnya laba usaha akan menarik investor untuk menanamkan sahamnya pada perusahaan tersebut sehingga laba ditahan perusahaan akan mengalami peningkatan. Begitu pula sebaliknya, jika modal kerja yang dimiliki perusahaan semakin kecil maka perusahaan akan memperoleh laba yang kecil pula. Jika perusahaan mengalami hal seperti ini maka akan mendorong pada terjadinya kesulitan keuangan dan perusahaan akan mengalami kebangkrutan.

\section{KESIMPULAN}

Penelitian ini digunakan untuk mengetahui apakah variabel rasio Altman Modifikasi berpengaruh terhadap prediksi kebangkrutan perusahaan property dan real estate yang terdaftar di Bursa Efek Indonesia. Berdasarkan hasil analisis dan uji hipotesis yang telah dilakukan dalam penelitian ini, maka dapat ditarik beberapa simpulan sebagai berikut:

1. Variabel Working Capital/Total Asset tidak berpengaruh terhadap prediksi kebangkrutan

2. Variabel Retained Earning/Total Asset tidak berpengaruh terhadap prediksi kebangkrutan

3. Variabel Earning Before Interest and Tax/Total Asset berpengaruh terhadap prediksi kebangkrutan

4. Variabel Market Value of Equity/Book Value of Debt tidak berpengaruh terhadap prediksi kebangkrutan

5. Variabel rasio Altman Modifikasi secara simultan atau bersama-sama berpengaruh terhadap prediksi kebangkrutan 
Berdasarkan hasil temuan dalam penelitian ini, maka penulis dapat memberikan saran-saran sebagai berikut:

1. perusahaan property dan real estate disarankan untuk lebih meningkatkan kemampuan menghasilkan laba (profitabilitas) untuk menghindari kebangkrutan perusahaan, misalnya dengan cara meminimalisir biaya dan meningkatkan pendapatan perusahaan sehingga laba akan meningkat. Karena rasio EBIT terhadap total aktiva perusahaan property dan real estate tergolong rendah.

2. Berdasarkan hasil pengujian rasio Altman Modifikasi secara simultan berpengaruh terhadap prediksi kebangkrutan. Maka, perusahaan yang sudah go public ataupun belum go public dapat menggunakan rasio Altman Modifikasi tersebut untuk mengukur kinerja keuangan dan memprediksi kebangkrutan perusahaan. Sehingga perusahaan dapat meningkatkan kinerjanya.

3. Bagi peneliti yang mempunyai keinginan mengadakan penelitian sejenis disarankan untuk menggunakan populasi dan sampel penelitian yang lebih luas serta menambah variabel penelitian, karena masih banyak faktor lain yang berperan untuk memprediksi kebangkrutan, misalnya rasio likuiditas, rasio leverage, rasio profitabilitas, rasio aktivitas, dan lainnya.

\section{DAFTAR PUSTAKA}

Altman, E.I. 1968. "Financial Ratios, Discriminant Analysis and The Prediction of Corporate Bankruptcy". The Journal of Finance Vol. XXIII No. 4, September 1968.

Darsono dan Ashari. 2005. Pedoman Praktis Memahami Laporan Keuangan. Yogyakarta: Andi.

Endri. 2009. "Prediksi Kebangkrutan Bank untuk Menghadapi dan Mengelola Perubahan Lingkungan Bisnis: Analisis Model Altman's Z-Score" Perbanas Quarterly Review, Vol.2 No.1 Maret 2009. http://www.pdfio.com/k-188685.html, Diakses tanggal 12 Maret 2015.

Fahmi, I. 2013. Analisis Laporan Keuangan. Bandung: Alfabeta.

Gamayuni, R.R. 2011. "Analisis Ketepatan Model Altman sebagai Alat untuk Memprediksi Kebangkrutan (Studi Empiris pada Perusahaan Manufaktur di BEI)". Jurnal Akuntansi dan Keuangan Vol. 16 No. 2, Juli-Desember 2011.

Ghozali, I. 2011. Aplikasi Analisis Multivariate dengan Program IBM SPSS 19. Semarang: Badan Penerbit Universitas Diponegoro.

Hanafi, M.M. dan Halim, A. 2012. Analisis Laporan Keuangan Edisi Keempat. Yogyakarta: UPP STIM YKPN.

Latan, H. dan Temalagi, S. 2013. Analisis Multivariate Teknik dan Aplikasi Menggunakan Program IBM SPSS 20.0. Bandung: Alfabeta.

Martha, Y. 2012." Analisis Prediksi Financial Distress Pada Perusahaan Ritel dan Wholesale yang Terdaftar di BEI Menggunakan Rasio Model Altman (Periode 2008-2011)”. http://jurnal.umrah.ac.id/wp-content/uploads/2013/08/Yuslely-Martha090462201395.pdf, diakses tanggal 31 Maret 2015

Maulana, H. 2010. "Prediksi Financial Distress pada Perusahaan Manufaktur Menggunakan Rasio Altman". http://ebook.library.perbanas.ac.id/2852_SKRIPSI\%20PDF.pdf, Diakses tanggal 31 Maret 2015.

Nugroho, M.I.D. dan Mawardi, W. 2012. "Analisis Prediksi Financial Distress dengan Menggunakan Model Altman Z-Score Modifikasi 1995 (Studi Kasus pada Perusahaan Manufaktur yang Go Public di Indonesia Tahun 2008-2010)". Diponegoro Journal of Management Volume 1, Nomor 1, Tahun 2012. 
Parahita. 2012. "Menghindari Potensi Kebangkrutan Perusahaan dengan Altman Z-Score", https://parahita.wordpress.com/2011/01/12/menghindari-potensi-kebangkrutanperusahaan-dengan-altman-z-score, Diakses tanggal 2 Maret 2015.

Prihadi, T. 2009. Investigasi Laporan Keuangan dan Anlisis Ratio Keuangan. Jakarta: Pengembangan Eksekutif.

Sartono, A. 2010. Manajemen Keuangan Teori dan Aplikasi. Yogyakarta: BPFE.

Sinarwati, N.K. 2012. "Z Score untuk Memprediksi Kebangkrutan”. Jurnal Riset Akuntansi Vol. 2, No.1: Program Studi Akuntansi Fakultas Ekonomi Universitas Maharaswati Denpasar.

Subramanyam, K.R. dan Wild, J.J. 2010. Analisis Laporan Keuangan Edisi 10 Buku 2. Jakarta: Salemba Empat.

Sugiyono. 2014. Metode Penelitian Kuantitatif, Kualitatif, dan Kombinasi (Mix Methods). Bandung: Alfabeta.

Sunyoto, D. 2013. Analisis Laporan Keuangan untuk Bisnis (Teori dan Kasus). Yogyakarta: CAPS. 